\title{
The Technology and Application of Improving Bearing Capacity of Deep Peat Soil Subgrade
}

\author{
CAO Xiuling ${ }^{1, *}$, YUE Muci ${ }^{2}$, XU Haiyan ${ }^{3}$, CHEN Song ${ }^{1}$,HOU Yongkang ${ }^{1}$, WANG Xingkuo ${ }^{1}$ \\ ${ }^{1}$ Hebei GEO University,School of Urban Geology and Engingeering,Shijizhuang,China,050031 \\ 2.Syracuse University,Department of Architecture,Syracuse,NY 13244. \\ ${ }^{3 .}$ China MC20 Group Corp.LTD,Shanghai, China 201900
}

\begin{abstract}
Peat soil is widely distributed in more than 500 countries around the world, covering an area of over 4 million square kilometers, among which the distribution area in China is about 40000 square kilometers, and most of Peat soil is distributed in swamps and forests. Peat soil is with high content of organic matter, poor engineering properties and low bearing capacity, which is very unfavorable to the safety and functionality of infrastructure construction. The Belt and Road, and the other two parts of the peat soil are studied in this paper. The key technologies of peat soil foundation are studied through literature review and comparative study. This will provide theoretical and technical support for repairing bridges, roads and houses in the distribution area of peat soil, and provide the theoretical basis and technical foundation for the construction of the "peat" Road area.

Chinese Library Classification: TU08
\end{abstract}

\section{1. introduction}

Peat soil refers to the soil in the river lake sedimentary low plain and mountain valley, due to long-term water accumulation, dense aquatic vegetation, under the condition of hypoxia, a large number of plant residues are decomposed insufficiently and accumulated to form a peat layer, which is mostly distributed in the low-lying areas of cold and humid areas. When the soil contains different organic matter, it will form different organic matter soil. When the content of organic matter exceeds a certain content, it will form peat soil. It has different engineering characteristics. The higher the content of organic matter, the greater the impact on the soil, mainly manifested as low strength, high compressibility, and different effects on the incorporation of different engineering materials. It has an adverse effect on direct engineering construction or foundation treatment. In order to eliminate the influence of peat soil on engineering, scholars at home and abroad have carried out a series of researches on the engineering characteristics of peat soil foundation and the methods to improve the bearing capacity of soft soil foundation, but there are few literatures on improving the bearing capacity of deep peat soil foundation, In order to provide theoretical basis and technical support for bridge construction, road construction and house construction on deep peat soil foundation, this paper puts forward the effective and applicable key technologies to improve the bearing capacity, and provides technical guarantee for the safety of construction projects on peat soil foundation.

\section{Types and engineering characteristics of peat soil}

\subsection{Types of peat soil}

The content of organic matter $\mathrm{Wu}$ in peat soil is generally $10 \% \mathrm{Wu} \leq 60 \%$, the color is dark gray or black, with fishy smell, the plant structure that has not been completely decomposed can be seen, the body swells after soaking in water, it is easy to disintegrate, there are plant residues floating in water, and the drying shrinkage phenomenon is obvious. According to the content of $\mathrm{Wu}$, it can be divided into three types: weak peat soil $(10 \% \mathrm{Wu} \leq 25 \%)$, medium peat soil $(25 \% \mathrm{Wu} \leq 40 \%)$ and strong peat soil $(40 \% \mathrm{Wu} \leq$ $60 \%$ ). According to the different conditions of peatland formation, it can be divided into: moss peatland and swamp peatland. The moss peatland is only formed by plants irrigated by rain water, and there is no direct connection between the surface layer and the surface water. Because of the large cell structure of this plant, its water holding capacity is also particularly strong. Therefore, during rainfall, the water level of the peat surface layer can be raised to a few centimeters below its top by the special water holding capacity of the bryophytes. The vertical exchange rate of water in mossy peat is quite slow. It usually takes about a day for rainwater to penetrate from the surface to the bottom of the peat, and it may take weeks to reach the bottom of the peat.After the death of plants, they are decomposed by the action of microorganisms and soil animals. In the humid

\footnotetext{
*corresponding author's e-mail address:caoxiuling@hgu.edu.cn
} 
or surface water environment, due to the lack of oxygen, the number of aerobic microorganisms decreases, which makes the decomposition of dead plants slow and forms the accumulation of organic matter. The accumulated organic matter is called peat, also called grass carbon or peat. In the natural state, the production and storage of organic matter is much greater than decomposition, and the land accumulating peat is called peat swamp or peat land.

\subsection{Engineering characteristics of peat soil}

The undrained strength of peat soil is usually only 5-30kpa, which shows that the basic value of bearing capacity is very low, generally not more than $70 \mathrm{kpa}$, some even only $20 \mathrm{KPa}$. The compression coefficient is greater than $0.5 \mathrm{mpa}-1$, the maximum is $45 \mathrm{mpa}-1$, and the compression index is about $0.35-0.75$. The value of the modulus of compressibility of peat soil has not been listed separately in the code, and its value can only be determined by soft soil or test. The settlement of sample soil can be measured by compression test, and the compression coefficient and compression modulus can be calculated. The shear strength parameters of sample soil can be determined by shear test, and the maximum bearing capacity of sample soil can be calculated.

\section{Methods of improving the bearing capacity of peat soil foundation}

\section{1 replacement method}

When the thickness of soft soil is less than $2 \mathrm{~m}$ and the height of embankment is low, this method is adopted. Firstly, all or part of the peat soil is excavated, and layered filling is carried out with materials with good water permeability (adding appropriate amount of cement and lime if necessary). The commonly used replacement materials are gravel, cobble, schist and other permeable materials or clay with high strength ${ }^{[2-4]}$. The characteristics and application scope of common replacement methods are shown in Table 1.

Table 1 features and application scope of common replacement methods

\begin{tabular}{|c|c|c|}
\hline Method & Features & Scope of Application \\
\hline $\begin{array}{l}\text { Soil change } \\
\text { cushion method }\end{array}$ & $\begin{array}{l}\text { Excavate weak soil or bad soil to a } \\
\text { certain depth, backfill rock and soil } \\
\text { materials with high shear strength and } \\
\text { less compressibility, such as sand, } \\
\text { gravel and concrete, and form a } \\
\text { double foundation. The cushion can } \\
\text { effectively spread the base stress, } \\
\text { which can improve the load force of } \\
\text { the foundation and reduce the } \\
\text { settlement }\end{array}$ & Various weak foundations \\
\hline $\begin{array}{l}\text { Squeesilt } \\
\text { replacement } \\
\text { method }\end{array}$ & $\begin{array}{l}\text { Strengthening foundation by blasting } \\
\text { or rammed backfill rubble, blasting } \\
\text { can be used }\end{array}$ & Silt or silty clay \\
\hline $\begin{array}{l}\text { Ramram } \\
\text { replacement } \\
\text { method }\end{array}$ & $\begin{array}{l}\text { Using the method of filling gravel and } \\
\text { strong compaction, form gravel pier } \\
\text { body in the foundation, with soil } \\
\text { between gravel piers and gravel } \\
\text { cushion to form composite foundation } \\
\text { to improve bearing capacity and } \\
\text { reduce settlement }\end{array}$ & Silty soil or soft clay foundation \\
\hline $\begin{array}{l}\text { Lime-pile } \\
\text { method }\end{array}$ & $\begin{array}{l}\text { Through mechanical or artificial } \\
\text { perforation, raw lime or raw lime are } \\
\text { added to the weak foundation, } \\
\text { through the lime water absorption } \\
\text { expansion and heat release and ion } \\
\text { exchange, improve the physical and } \\
\text { mechanical properties of pile and soil, } \\
\text { form the composite foundation of } \\
\text { lime pile, improve the bearing } \\
\text { capacity and reduce the settlement }\end{array}$ & $\begin{array}{l}\text { Mixed fill soil, soft clay } \\
\text { foundation }\end{array}$ \\
\hline
\end{tabular}


as to achieve the purpose of foundation treatment. The characteristics and application scope of common vibration

compaction extrusion method see table 2.

Table 2 characteristics and application scope of commonly used vibration compaction extrusion method

\begin{tabular}{c|l|c}
\hline Method & \multicolumn{1}{|c}{ Features } & Scope of Application \\
\hline Ramming method & $\begin{array}{l}\text { Use the rammer with 10 40t mass to fall } \\
\text { freely from the height, and the foundation } \\
\text { soil is dense under the impact force and } \\
\text { vibration force of the strong compaction, } \\
\text { which can improve the load capacity of } \\
\text { the foundation and reduce the settlement }\end{array}$ & $\begin{array}{c}\text { Gravel soil, sand soil, low saturation } \\
\text { silt and clay soil, collapsible loess, } \\
\text { miscellaneous fill soil and plain fill } \\
\text { soil and foundation }\end{array}$ \\
\hline Squeeded and & $\begin{array}{l}\text { Gravel pile is set in the foundation by } \\
\text { vibrational pipe sinking method, with the } \\
\text { gravel pile method } \\
\text { layer during the pile making, forming the } \\
\text { composite foundation to achieve the } \\
\text { purpose of improving the foundation } \\
\text { bearing capacity and reducing the } \\
\text { settlement }\end{array}$ & $\begin{array}{c}\text { Sand and soil foundation, unsaturated } \\
\text { and cohesive land foundation }\end{array}$ \\
\hline
\end{tabular}

\subsection{Drainage consolidation method}

Drainage consolidation method is a kind of foundation reinforcement method, which can improve the strength of foundation soil by preloading the natural foundation or the foundation with vertical drainage body before the construction of buildings, so that the consolidation settlement of soil is basically completed or most of it is completed. Using this method to treat the soft foundation, the foundation settlement relative to the preloading load can be partially or basically eliminated during the treatment period, so that the building will not produce excessive settlement or settlement difference during the use period. At the same time, through drainage consolidation, the increase of shear strength of foundation soil is accelerated, and the strength and stability of building foundation are improved. The drainage consolidation system consists of loading system and drainage system, as shown in Figure 1. The characteristics and application scope of common drainage consolidation methods See Table 3.

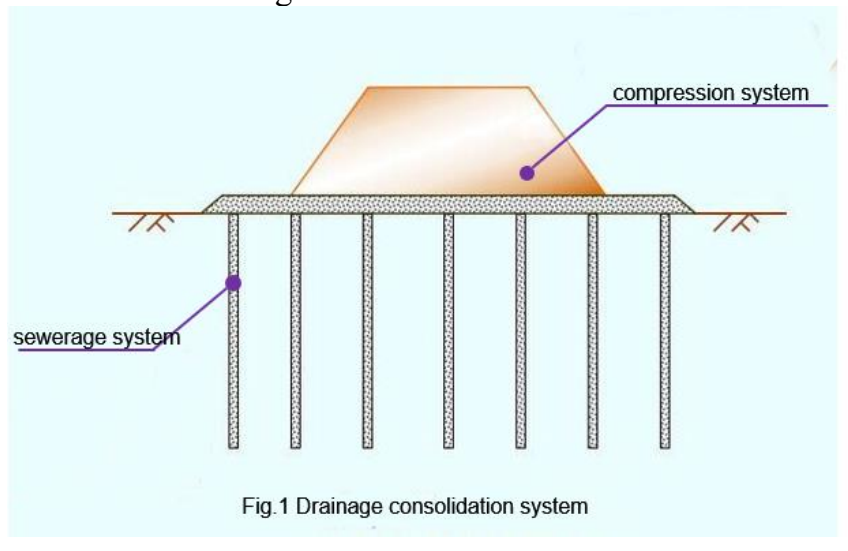

Table 3 characteristics and application scope of common drainage consolidation methods

\begin{tabular}{c|l|c}
\hline Method & \multicolumn{1}{c}{ Features } & \multicolumn{1}{c}{ Scope of Application } \\
\hline \multirow{5}{*}{$\begin{array}{c}\text { Loading } \\
\text { preloading method }\end{array}$} & $\begin{array}{l}\text { Drainage channel and vertical drainage } \\
\text { system are set in the foundation to reduce } \\
\text { the drainage distance of soil consolidation, } \\
\text { and the foundation performs drainage } \\
\text { consolidation under the filling } \\
\text { embankment load, improve the bearing }\end{array}$ & Soft clay, miscellaneous fill, peat soil \\
& $\begin{array}{l}\text { capacity of the foundation and reduce the } \\
\text { settlement after work }\end{array}$ & \\
\hline \multirow{5}{*}{$\begin{array}{l}\text { Overload } \\
\text { preloading method }\end{array}$} & $\begin{array}{l}\text { loading precompression method, and the } \\
\text { difference is that the prepressure load is } \\
\text { greater than the design use load, which } \\
\text { can not only reduce the secondary } \\
\text { consolidation settlement, but also }\end{array}$ & Soft clay, miscellaneous fill, peat soil \\
\end{tabular}




\begin{tabular}{c|l|l}
\hline & $\begin{array}{l}\text { eliminate some secondary consolidation } \\
\text { settlement }\end{array}$ & \\
\hline $\begin{array}{c}\text { Vacuum combined } \\
\text { stacking } \\
\text { prepressure }\end{array}$ & $\begin{array}{l}\text { Drainage system (dbid.) is set in the soft } \\
\text { clay foundation, and then form an airtight } \\
\text { layer on it. Through continuous pumping } \\
\text { for a long time, a negative pressure area is } \\
\text { formed in the foundation to achieve soft } \\
\text { clay soil drainage and consolidation to } \\
\text { improve bearing capacity and reduce } \\
\text { settlement, and often used combined with } \\
\text { stacking pre-pressure }\end{array}$ & Soft-clay foundation \\
$\begin{array}{c}\text { Reducing the } \\
\text { underground water } \\
\text { level method }\end{array}$ & $\begin{array}{l}\text { By reducing the underground water level, } \\
\text { the effect of changing the foundation soil, } \\
\text { such as loading and loading, strengthens } \\
\text { the foundation soil }\end{array}$ & $\begin{array}{c}\text { Sand soil or soft clay soil foundation } \\
\text { with good water permeability }\end{array}$ \\
\hline
\end{tabular}

\subsection{Reinforcement method}

Reinforcement method refers to laying geosynthetics (or steel strip, steel bar, reinforced concrete (string) belt, nylon rope, etc.) in the embankment or retaining wall of artificial filling, or driving tensile materials such as soil anchor (or soil nail, tree root pile) into the slope, relying on them to limit the deformation of soil, improve the mechanical properties of soil, and improve the strength and stability of soil. Its mechanism is that through the friction between the soil and the reinforcement, the tensile stress in the soil is transferred to the reinforcement, and the reinforcement bears the tensile force, while the soil between the reinforcement bears the compressive stress and shear stress, so that the reinforcement and the soil in the reinforced soil can better play their potential ${ }^{[6]}$. The characteristics and application scope of common reinforcement methods are shown in Table 4.

Table 4 features and application scope of common reinforcement method

\begin{tabular}{c|l|c|c}
\hline Method & \multicolumn{1}{c}{ Features } & Scope of Application \\
\hline $\begin{array}{c}\text { Reinforced cushion } \\
\text { method }\end{array}$ & $\begin{array}{l}\text { Lay the reinforced material (such as } \\
\text { geotechnical fabric, geotechnical barrier, } \\
\text { te.) in the foundation to form a reinforced } \\
\text { cushion to increase the pressure diffusion } \\
\text { angle. Improve the foundation stability }\end{array}$ & All kinds of weak foundation \\
\hline $\begin{array}{c}\text { Low-strength } \\
\text { concrete pile }\end{array}$ & $\begin{array}{l}\text { Low-strength concrete piles are set in the } \\
\text { foundation to form a composite } \\
\text { foundation with the soil between the piles. } \\
\text { Reduce settlement, such as pile CFG }\end{array}$ & $\begin{array}{c}\text { All kinds of deep and weak } \\
\text { foundation }\end{array}$ \\
\hline $\begin{array}{c}\text { Reinforced } \\
\text { concrete pile }\end{array}$ & $\begin{array}{l}\text { Low-strength concrete piles are set in the } \\
\text { foundation to form a composite } \\
\text { foundation with the interpile soil. Reduce } \\
\text { the settlement }\end{array}$ \\
\hline $\begin{array}{c}\text { Long and short pile } \\
\text { composite } \\
\text { foundation }\end{array}$ & $\begin{array}{l}\text { The composite foundation is formed from } \\
\text { long pile and short pile and pile soil. } \\
\text { Improve the foundation bearing force and } \\
\text { reduce the settlement, adopt the same pile } \\
\text { or non-pile type }\end{array}$ \\
\hline
\end{tabular}

\section{4 engineering application}

One belt, one road project, is the first highway in Cartu Nayak, Colombo, Sri Lanka. It is known as the first road in Sri Lanka. It is adjacent to the India ocean, with a total length of $25.8 \mathrm{~km}$. The main roads are marshes and drainage lakes. The soft foundation roads of peat soil and $13.7 \mathrm{~km}$ are the largest, and the peat soil is $20 \mathrm{~m}$, with an average depth of $8 \mathrm{~m}$. Because the depth of peat soil is deep, if the sand cushion method and replacement method are used, the project quantity is large, the construction period is long and the cost is high, the reinforcement of soil pile, pile preloading and gravel pile are selected for reinforcement after study ${ }^{[7]}$. The project adopts the method of pile preloading and gravel pile, and has achieved good results, and the difference deformation is controlled within the allowable range. 


\section{Conclusion}

The method of improving the bearing capacity of deep peat soil subgrade with depth greater than $8 \mathrm{~m}$ can be combined with surcharge preloading and gravel pile. The engineering practice shows that the effect is very good, and similar projects can be used for reference.

\section{Acknowledgments}

This work was supported by the Hebei Province Talent Introduction Project (NO.D2018014), the Hebei Province High-level Talent Funding Project (NO.E2018050005), and the Hebei Province Innovative Talent Project (NO.D2020216). International cooperation and innovation project (NO.D20210601) support.

\section{References}

1. HUAT B B K, KAZEMIAN S, PRASAD A, et al. State of an art review of peat: General perspective $[\mathrm{J}]$. International Journal of the Physical Sciences, 2011, 6(08): 1988-1996.

2. MESRI G, ASCE M, AJLOUNI $M$, et al. Engineering properties of fibrous peats[J]. Journal of Geotechnical and Geoenvironmental Engineering, 2007, 133(7): 850-866.

3. WONG L S, HASHIM R, ALI F H. A review on hydraulic conductivity and compressibility of peat[J]. Journal of Applied Sciences, 2009, 9(18): 3207-3218.

4. Wang Yang, Qin xiaqiang, Lou Jianjun, Zhang Qi, Zhu song, GUI Yue. Study on physical and mechanical properties of Sri Lanka peat soil [J]. Highway,2020,65(05):258-264.

5. SANTAGATA M, BOBET A, JOHNSTON C $\mathrm{T}$, et al. One-dimensional compression behavior of a soil with high organic matter content $[\mathrm{J}]$. Journal of Geotechnical and Geoenvironmental Engineering, 2008, 134( 1) : $1-13$

6. GUI Yue, Fu Jian, Hou Yingjie, Cao Jing, Zhou Yundong. Characteristics and mechanism of direct shear strength of high resolution peat soil [J]. Journal of Hohai University (NATURAL SCIENCE EDITION),2016,44(05):418-426.

7. SOBHAN K, ALI H, RIEDY K, et al. Fieldand laboratory compressibility characteristics of soft organic soils in florida[C]// Advances in Measurement and Modeling of Soil Behavior.ASCE, 2007: 1-10. 